\title{
Microbiological Quality of Organic and Conventional Leafy Vegetables
}

\section{Vanessa Vanderléia Merlini, Fabíola de Lima Pena, Diogo Thimoteo da Cunha $\mathbb{D}$, Julicristie Machado de Oliveira, Mauricio Ariel Rostagno $(\mathbb{D}$, and Adriane Elisabete Costa Antunes}

Faculdade de Ciências Aplicadas, Universidade de Campinas, Limeira, SP, Brazil

Correspondence should be addressed to Diogo Thimoteo da Cunha; diogo.cunha@fca.unicamp.br

Received 3 October 2017; Revised 4 January 2018; Accepted 14 January 2018; Published 8 February 2018

Academic Editor: Amy Simonne

Copyright (C) 2018 Vanessa Vanderléia Merlini et al. This is an open access article distributed under the Creative Commons Attribution License, which permits unrestricted use, distribution, and reproduction in any medium, provided the original work is properly cited.

\begin{abstract}
The aim of this study was to assess the microbiological profile of leafy vegetables from organic and conventional farming $(n=70)$. The microbiological parameters analyzed consisted of aerobic mesophilic bacteria, yeasts and molds, coliforms at 30 and $45^{\circ} \mathrm{C}$, and Salmonella ssp. A biochemical identification of the Enterobacteriaceae species was carried out. Some Enterobacteriaceae species were identified in the produce from both farming systems and Hafnia alvei was the most widespread specie observed. Salmonella spp. was not detected in the samples analyzed. The microbial counts for indicator microorganisms were, in general, higher for conventional leaves when compared to those produced by organic farming.
\end{abstract}

\section{Introduction}

The organic food and beverage market sold about 81.6 billion US dollars' worth of produce worldwide in 2015. Nowadays, the highest per capita consumption of organic food is found in European countries, such as Switzerland, Luxembourg, and Denmark [1]. The Institute of Development Promotion (IPD-Instituto de Promoção do Desenvolvimento) estimated there were more than 10,000 organic production units in Brazil in 2014. However, the lack of accurate data about the Brazilian market limits a precise number, since the majority of sales occur directly between small farmers and consumers [2].

The reasons for the consistent growth in the consumption of organic vegetables go from ethical and political reasons to life quality, safety, and environmental concerns $[3,4]$. Organic vegetables, generally, presents lower amount residues of pesticides when compared with conventional ones [5]. This fact increases consumer trust in organic food due to a lower perceived risk and increased perceived quality [6]. Perceived quality is one of the most important predictors of organic willingness to buy and consume [4]. The French Agency for Food Safety (ANSES) points out that the use of safe chemicals, such as alcohols and chlorine compounds, and the banishment of Genetically Modified Organisms (GMOs) constitute the most significant characteristics of organic production [7].

The relationship between microbiological risk and organic production is still uncertain since many factors may contribute to the development of microorganisms, including differences between the cropping system. The use of animal manure in organic farming naturally raises concern about the microbiological safety. Since there is a restriction concerning the chemicals allowed in organic production [8] the potential for microbial contamination exists when this type of fertilization is used, representing an increased risk to public health [9-11]. In Brazil the use of manure in organic agriculture is allowed; however, the composting of manure into soils is mandatory for this cropping system [12].

In some scientific studies greater risk with the consumption of organic food was not identified $[8,13]$ but controversially, several foodborne disease outbreaks are related to organic food [14]. One example is the outbreak of Shiga toxin-producing Escherichia coli O157:H7 linked with organic 
TABLE 1: Summary of the characteristics of the two evaluated farms.

\begin{tabular}{|c|c|c|c|c|}
\hline Location & Fertilization & Water source & Irrigation system & Irrigation system definition ${ }^{*}$ \\
\hline $\begin{array}{l}\text { Farm of organic } \\
\text { cultivation }\end{array}$ & $\begin{array}{l}\text { Manual with } \\
\text { manure composting }\end{array}$ & $\begin{array}{c}\text { Well water } \\
\text { (groundwater) }\end{array}$ & $\begin{array}{l}\text { Microirrigation (drip } \\
\text { and microspray) }\end{array}$ & $\begin{array}{l}\text { Applies the water through small emitter to } \\
\text { the soil surface; drip irrigation allows the } \\
\text { water to drip slowly to the roots of plants } \\
\text { minimizing the water evaporation; } \\
\text { microspray applies water to the soil surface } \\
\text { by a small spray or mist }\end{array}$ \\
\hline $\begin{array}{l}\text { Farm of conventional } \\
\text { cultivation }\end{array}$ & $\begin{array}{l}\text { Manual with } \\
\text { manure }\end{array}$ & $\begin{array}{c}\text { River water (surface } \\
\text { water) }\end{array}$ & Sprinklers & $\begin{array}{l}\text { Sprinkler irrigation is a method similar to } \\
\text { natural rainfall; water is delivered through a } \\
\text { pressurized pipe network to sprinklers } \\
\text { which spray the water into the air }\end{array}$ \\
\hline
\end{tabular}

* Source: Solomon et al. [23].

spinach consumption reported in five States of United States affecting 33 persons in 2012 [15]. No deaths were reported; however two persons developed hemolytic uremic syndrome (HUS).

Leafy vegetables do not generally represent the main type of food reported in outbreaks. From 1998 to 2008 only 5.2\% of bacterial foodborne illnesses in the USA were related to leafy vegetables [16]. The data from the Brazilian Health Ministry shows that vegetables represented about $0.8 \%$ of this epidemiology in the last 10 years; but this proportion could be higher because most outbreaks are subnotified in the USA [17] and Brazil. In addition, raw vegetables must be sanitized before consumption. However, food handlers, both professional and domestic, fail to follow hygiene procedures, increasing the risk of consuming raw vegetables [18, 19].

In this context, the present work proposes to microbiologically evaluate certified organic leafy vegetables and conventional ones from the same cultivars.

\section{Material and Methods}

2.1. Sampling. Samples of leafy vegetables from organic and conventional cultivation were obtained from two farms located in Cordeiropolis $\left(22^{\circ} 28^{\prime} 55^{\prime \prime} \mathrm{S} ; 47^{\circ} 27^{\prime} 24^{\prime \prime} \mathrm{O}\right)$ and Americana $\left(22^{\circ} 44^{\prime} 21^{\prime \prime} \mathrm{S} ; 47^{\circ} 19^{\prime} 53^{\prime \prime} \mathrm{O}\right)$, both cities in Sao Paulo State, Brazil. The production area for organic cultivation has 12 hectares where 50 different species of vegetables are planted. Well water is used for irrigation which is performed by microirrigation (drip and microspray irrigation). The fertilization is manual and made with manure composting into soils. The vegetables are collected by a work team composed of 8 persons, and each employee is responsible for the collection of a particular plant in order to observe possible changes in the crop. The organic vegetables presented national certification by Ecocert (a system which adopts external audits) and the leafy vegetables that have been evaluated are produced organically there since 2014 . The production area for conventional agriculture has 1.5 hectares, in which 19 different species of vegetables are grown throughout the year. The irrigation process is only by sprinkling and the irrigation water comes from a river from to the PCJ watersheds (belonging to Piracicaba, Corumbataí and Jaguari cities). Manure is also used for fertilization using a manual process. The work team is composed by 3 employees. Both producers used the same plant seedlings from the same provider, so the production only differed with respect to the type of cultivation. Five units of each leafy vegetable, organically and conventionally grown, were collected. The following species were analyzed: green leaf lettuce varieties "Milena" (LM) and "Vanda" (LV) and iceberg lettuce (IL) (Lactuca sativa L.), common chicory (CC) (Cichorium intybus), escarole (ES) (Cichorium endivia), collard greens (CG) (Brassica oleracea L.), and parsley (PA) (Petroselinum crispum). Table 1 summarizes the characteristics of the two farms.

The analyses were performed from February to November 2016. The analysis routine was the following: each type of leafy vegetable obtained by conventional and organic cultivation was harvested at the same day and taken to the Microbiology Laboratory. All analyses were performed on the day the vegetables were harvested. They were placed in plastic bags without modifying the atmosphere and stored at $4 \pm 3^{\circ} \mathrm{C}$ until analyzed. All samples presented a fresh appearance at the time of analysis. The vegetables were washed in running water before analysis, leaf by leaf, immersed in a sodium hypochlorite solution $(200 \mathrm{mg} / \mathrm{L})$ for 15 minutes, and then rinsed in running water [20]. This step aimed to compare the microbiological quality of the leave vegetables under the consumption conditions. Both the conventional and organic leafy vegetables of the same type/variety were analyzed at the same time and under the same conditions. Since the production areas are nearby (approximately $40 \mathrm{Km}$ distant), the conditions of climate and rain during cultivation were equivalent for each type of leafy vegetable growth at the same time.

2.2. Microbiological Analyses. The samples were analyzed for aerobic mesophilic bacteria, yeasts and molds, coliform (at $30^{\circ} \mathrm{C}$ and $45^{\circ} \mathrm{C}$ ) counts according to Downes and Ito [21], and the presence of Salmonella according to Andrews and Hammack [22].

Plate Count Agar (PCA) (Difco/BD, USA) was used for the aerobic mesophilic bacterial count with the addition of $1 \%$ triphenyl tetrazolium chloride (TTC) (Merck, USA), using the pour plate technique and incubation at $35 \pm 1^{\circ} \mathrm{C} / 48 \mathrm{~h}$. To determine the yeast and mold counts, the spread plate 
TABle 2: Mean counts of aerobic mesophilic bacteria, yeasts and molds, and coliforms at $30^{\circ} \mathrm{C}$ and $45^{\circ} \mathrm{C}$ from 70 vegetable samples from organic and conventional cultivation.

\begin{tabular}{|c|c|c|c|c|c|}
\hline \multirow{2}{*}{ Microorganism } & \multicolumn{2}{|c|}{ Conventional } & \multicolumn{2}{|c|}{ Organic } & \multirow{2}{*}{$p$ value } \\
\hline & Mean & $\mathrm{SD} \pm$ & Mean & $\mathrm{SD} \pm$ & \\
\hline Aerobic mesophilic bacteria $(\log \mathrm{CFU} / \mathrm{g})$ & 4.84 & 0.83 & 4.32 & 1.13 & $0.056^{*}$ \\
\hline Yeasts and molds $(\log \mathrm{CFU} / \mathrm{g})$ & 3.18 & 0.78 & 2.81 & 0.85 & $\mathbf{0 . 0 4 ^ { \dagger }}$ \\
\hline Coliforms at $30^{\circ} \mathrm{C}(\log \mathrm{MPN} / \mathrm{g})$ & 1.96 & 0.97 & 1.08 & 1.02 & $<0.01^{\dagger}$ \\
\hline Coliforms at $45^{\circ} \mathrm{C}(\log \mathrm{MPN} / \mathrm{g})$ & 0.79 & 0.88 & 0.25 & 0.27 & $<0.01^{\dagger}$ \\
\hline
\end{tabular}

$\mathrm{SD}$ is standard deviation. Values in bold indicate significant statistical difference $(p<0.05) .{ }^{*}$ Student's $t$-test. ${ }^{\dagger}$ Mann-Whitney's $U$ test.

technique was adopted using Sabouraud Dextrose Agar and incubation at $25 \pm 1^{\circ} \mathrm{C}$ for 3 to 5 days. All results were expressed in $\log \mathrm{CFU} / \mathrm{g}$.

The coliform counts at $30^{\circ} \mathrm{C}$ and $45^{\circ} \mathrm{C}$ were obtained using the Conventional Multiple Tube Technique with Lauryl Sulfate Tryptose Broth (Oxoid, England) and Brilliant Green Bile Broth (Oxoid, England), with incubation at $35 \pm$ $1^{\circ} \mathrm{C} / 48 \mathrm{~h}$. Positive samples were transferred to EC broth (Difco/BD, USA), with incubation at $45 \pm 1^{\circ} \mathrm{C} / 24 \mathrm{~h}$. The results were expressed as the log most probable number per gram $(\log \mathrm{MPN} / \mathrm{g})$.

The method described by Andrews and Hammack [22] was used to evaluate the presence of Salmonella. Briefly, the method consists of the following steps: (A) preenrichment (Lactose Broth, Difco/BD, USA); (B) selective enrichment (Tetrathionate broth (TT) and Selenite Cysteine broth (SC), Oxoid, England); (C) differential plating (Hektoen Enteric agar (HE), Salmonella Shigella agar (SS) and Xylose-LysineDesoxycholate agar (XLD), Oxoid, England); and (D) biochemical tests (Lysine Iron Agar (LIA) and Triple Sugar Iron agar (TSI), Difco/BD, USA). After application, each culture medium was incubated at $35^{\circ} \mathrm{C} / 24 \mathrm{~h}$, and when a positive reaction was obtained in the biochemical tests, a serological test was carried out using polyvalent antisera (Probac, Brazil).

2.3. Biochemical Identification of the Enterobacteriaceae. To identify the species of Enterobacteriaceae present in the samples, the commercial systems Bactray ${ }^{\circledR}$ I and II (Laborclin, Brazil) were used. These consist of a miniature kit indicated for gram-negative oxidase negative bacilli, glucosefermenting and glucose nonfermenting bacteria. Initially, MacConkey media for the growth of typical colonies was used, with incubation at $35^{\circ} \mathrm{C} / 48 \mathrm{~h}$, and then transferred to Brain Heart Infusion broth (BHI) and incubated at $35^{\circ} \mathrm{C} / 24 \mathrm{~h}$. The BHI broth was adjusted to a $0.5 \mathrm{McF}$ arland turbidity reading in a spectrophotometer at $600 \mathrm{~nm}$.

An aliquot of $1.0 \mathrm{~mL}$ of the suspension was then transferred to the Bactray I and II systems and incubated at $35^{\circ} \mathrm{C} / 18 \mathrm{~h}-24 \mathrm{~h}$. An electronic program provided by Laborclin revealed the species found.

2.4. Reference Standards. The data obtained were compared with the Brazilian legislation (RDC no. 12) (Resolução da Diretoria Colegiada $=$ Resolution of the Board of Directors) which indicates a maximum count for coliform bacteria at $45^{\circ} \mathrm{C}$ of $2 \log \mathrm{CFU} / \mathrm{g}$ and the absence of Salmonella in $25 \mathrm{~g}$ [24]. The Compendium of Methods for the Microbiological
Examination of Foods published by the American Public Health Association (APHA) was also consulted in order to establish the parameters not contemplated by the Brazilian legislation [21].

2.5. Statistical Analysis. The variables were expressed as the means followed by the standard variation. The distribution histograms, mean, standard deviation, and minimal and maximum values were verified. The Kolmogorov Smirnov test was used to verify the adherence of distributions with the normal curve.

The means obtained for organic and conventional cultivation were compared using Student's $t$-test (variables with normal distribution and homoscedasticity) or Mann-Whitney's $U$ (variables without normal distribution and/or homoscedasticity). All tests were carried out using the SPSS software version 15.0.1., considering a significance level of $p<0.05$.

\section{Results and Discussion}

The comparison between aerobic mesophilic bacteria, coliforms at $30^{\circ} \mathrm{C}$ and $45^{\circ} \mathrm{C}$, and yeasts and molds can be observed in Table 2 (mean counts for each group of microorganism) and Figure 1 (mean counts for each leafy vegetable). Leafy vegetables from conventional cultivation presented higher mean counts of coliforms at $30^{\circ} \mathrm{C}$, coliforms at $45^{\circ} \mathrm{C}$, and yeasts and molds than the organically grown ones.

Of all the samples analyzed, only one conventional vegetable (LV) and two organic ones (LM and CC) presented aerobic mesophilic bacterial counts higher than $6 \log \mathrm{CFU} / \mathrm{g}$, but they showed no signs of deterioration. When the aerobic mesophilic bacterial counts reach $6 \log \mathrm{CFU} / \mathrm{g}$, the vegetables may show signs of deterioration and become unsuitable for consumption [25].

A range from 4 to $>7 \log \mathrm{CFU} / \mathrm{g}$ for yeasts and molds in organic and conventional vegetables was reported by the literature $[26,27]$. In the present work mean counts for yeasts and molds for each leafy vegetable were lower than $4 \log \mathrm{CFU} / \mathrm{g}$; however the samples were sanitized before analysis.

The contamination with coliforms at $30^{\circ} \mathrm{C}$ found presently reached $1.08 \log \mathrm{MPN} / \mathrm{g}$ for organic vegetables and $1.96 \log \mathrm{MPN} / \mathrm{g}$ for conventional vegetables. Even though high levels of coliforms at $30^{\circ} \mathrm{C}$ may not represent an eminent health risk, they suggest poor hygiene conditions. A study with organic lettuces cultivated in Brazil [28] showed a range from 2.7 to $\geq 3.38 \log \mathrm{MPN} / \mathrm{g}$ for coliforms at $30^{\circ} \mathrm{C}$. 


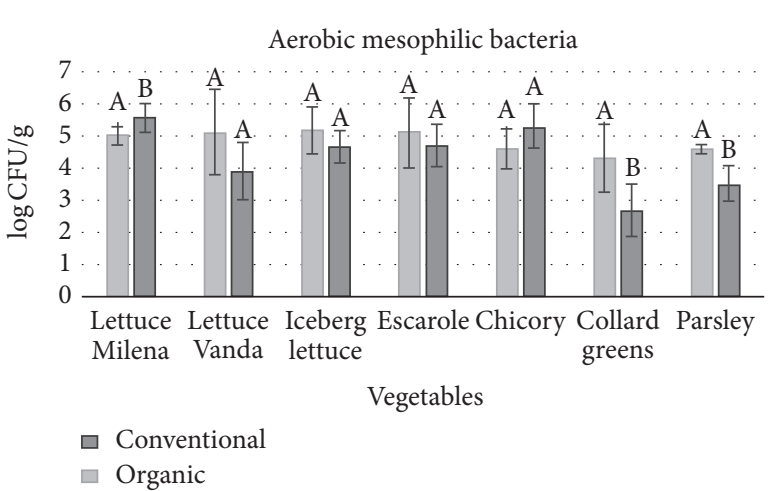

(a)

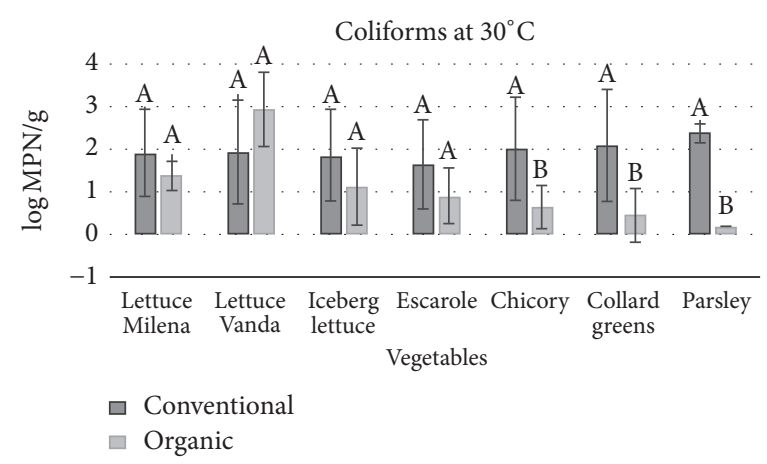

(c)

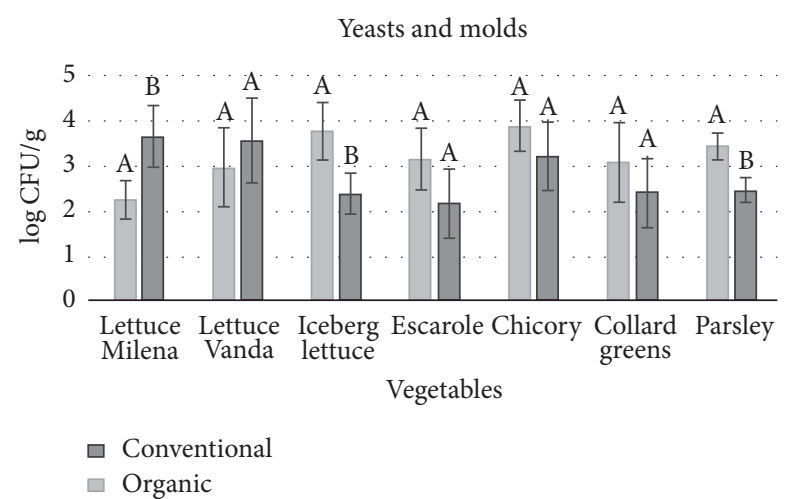

(b)

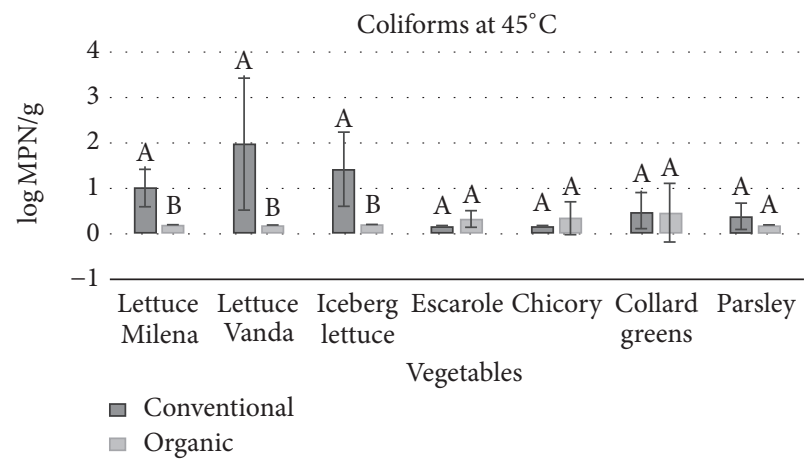

(d)

Figure 1: Counting of aerobic mesophilic bacteria (a), yeasts and molds (b), and coliforms at $30^{\circ} \mathrm{C}$ (c) and $45^{\circ} \mathrm{C}(\mathrm{d})$ among the 7 species of organic and conventional vegetables. Equal letters for the same vegetable indicate no statistical difference in Student's $t$-test $(p<0.05)$.

The occurrence of coliforms at $45^{\circ} \mathrm{C}$ can indicate fecal contamination. Lotto and Valarini [29] showed that conventional lettuces produced in Brazil presented higher counts for coliforms at $45^{\circ} \mathrm{C}$ than organic lettuces, in accordance with the results of the present study, where the three types of lettuce evaluated presented statistically higher counts for coliforms at $45^{\circ} \mathrm{C}$ for conventional leaves (Figure 1(d)). For fresh, unpacked, unprocessed, and sanitized vegetables, the maximum count accepted for coliforms at $45^{\circ} \mathrm{C}$ is $2 \log$ MPN/g [24].

There was a statistical difference between the microbial load (i.e., coliforms at $30^{\circ} \mathrm{C}$ and at $45^{\circ} \mathrm{C}$ and yeasts and molds) of the leafy vegetables obtained by the two cultivation systems; however, the absolute numbers of the counts were similar, less than 1 log different. Although the averages were close, in the individual analyses of two conventionally cultivated leafy vegetables (LV (Vanda lettuce) and IL (iceberg lettuce)) higher counts of coliforms were observed at $45^{\circ} \mathrm{C}$ than the established by the Brazilian legislation [12] indicating risk to the consumers.

The presence of Salmonella spp. was not detected in any of the samples analyzed. Some studies refer to the absence of Salmonella spp. in fresh vegetables from the Brazilian market $[26,30]$; however other researchers found the presence of Salmonella in a range from 0.7 to $20 \%$ of the samples $[7,28,31]$.

In some Brazilian studies, higher microbial counts were observed for organic vegetables $[7,26,28,32]$ than for conventional ones. However, the microbial comparison of organic and conventional vegetables is controversial and depends on several factors including inadequately composted or raw animal manure and irrigation with bad quality water $[7,8,33]$.

The irrigation system is another important factor in the microbiological safety of a crop, since contaminated water can reach the leaves during irrigation [3]. The control of this source of contamination has been indicated as one of the most promising targets to reduce microbial contamination [34]. During this study, technical visits were made to both production areas (conventional and organic cultivation). The agricultural production unit responsible for the organic vegetables uses good quality water and microirrigation systems. On the other hand, the conventional unit uses river water with just a sprinkler system. According to ICMSF [35] good quality water is less susceptible to contamination by pathogens than surface water taken from rivers, for example. Groundwater commonly contains less organic matter and microorganisms than surface water because the rock tends to act as a filter to remove some contaminants. Considering these aspects, the source and type of irrigation used may have affected the results.

The indiscriminate use of herbicides and pesticides in conventional agriculture systems has been indicated as one of the causes of water and soil contamination and an imbalance in the environment, with direct impacts on the microbial 
TABLE 3: Enterobacteriaceae species identified by miniature kits Bactray I and II from samples of organic and conventional cultivation of leafy vegetables.

\begin{tabular}{|c|c|c|c|c|}
\hline \multirow{2}{*}{ Vegetable } & \multicolumn{4}{|c|}{ Enterobacteriaceae } \\
\hline & Conventional & Precision rate $(\%)$ & Organic & Precision rate $(\%)$ \\
\hline Iceberg lettuce (Lactuca sativa L.) & N.D. & & N.D. & \\
\hline Lettuce, var. Milena (L. sativa L.) & N.D. & - & Pantoea dispersa & 49.96 \\
\hline \multirow{2}{*}{ Lettuce, var. Vanda (L. sativa L.) } & \multirow{2}{*}{ N.D. } & & Yokenella regensburgei & 84.55 \\
\hline & & & Hafnia alvei & 99.85 \\
\hline Escarole (Cichorium intybus) & Pseudomonas luteola & 51.83 & Pseudomonas luteola & 51.83 \\
\hline \multirow{3}{*}{ Chicory (Cichorium endívia) } & Acinetobacter baumannii/calcoaceticus & 100 & \multirow{3}{*}{ N.D. } & \\
\hline & Hafnia alvei & 100 & & - \\
\hline & Klebsiella oxytoca & 99.2 & & \\
\hline \multirow{2}{*}{ Collard green (Brassica oleracea L.) } & Hafnia alvei & 100 & \multirow{2}{*}{ N.D. } & \\
\hline & Enterobacter asburiae & 44.97 & & \\
\hline Parsley (Petroselinum crispum) & Hafnia alvei & 100 & Hafnia alvei & 100 \\
\hline
\end{tabular}

N.D.: no species detected.

loads of the soil and on several other species [36]. On the other hand, some studies have shown that organic fertilizers can benefit the soil microbiota, increasing the availability and uptake of nutrients and also contributing to plant growth [37]. Although animal manure benefits the soil microbiota and can be used as a fertilizer in both organic and conventional farming, the risks in the case of organic production can be higher. To minimize this problem, a composting process is recommended, which involves mineralization, moisturizing, and decomposition of the organic matter, resulting in a stable, pathogen free product with an improved nutrient content [38]. During the thermophilic phase of composting, the temperature can rise to $60^{\circ} \mathrm{C}$ and this is enough to reduce the microbiological counts, including those of pathogens [39]. Costa et al. [40] demonstrated that the coliform population suffered a progressive reduction during composting, and Enterobacteriaceae such as Salmonella were destroyed. The use of composting is mandatory for organic farmers in Brazil, as described in Normative Instruction number 46 [12]. However, for conventional agriculture, although the use of manure is allowed, composting is not required. It is suggested that composting must be required by Brazilian government in both the organic and conventional systems given the importance of this process in product safety.

Table 3 shows the counts for the Enterobacteriaceae species found on the samples of leafy vegetables. The specie present in most samples was Hafnia alvei, which was found in both organic and conventional produce. Other genera/species identified in the samples were Pseudomonas luteola, Acinetobacter baumannii/calcoaceticus, Klebsiella oxytoca, Enterobacter asburiae, Pantoea dispersa, and Yokenella regensburgei. Although Enterobacteriaceae are present in the soil, water, plants, and the human microbiota, they can be a source of foodborne diseases. Some species observed in the present study in both organic and conventional leaves are epiphytic bacteria, which commonly colonize on the surface of plants [41]. Their occurrence was also documented by Al-Kharousi et al. [42] in about $91 \%$ of vegetable samples.
Although not necessarily harmful to the vegetables themselves, all the species found here have been somehow related to hospital-acquired infections. Hafnia alvei appeared 5 times in this study and can be found in human and animal feces, as well as in water, soil, and diverse products of animal origin [43] playing a role in the spoilage of refrigerated meat and vegetables [44]. Moreover, $H$. alvei can be resistant to penicillin, ampicillin, cephalothin, tetracycline, and amoxicillin/clavulanic acid $[45,46]$ which can represent a threat from the clinical perspective.

It is also important to point out that, with respect to the species reported in the current study, the reports found in the literature concerning infections caused by them occurred mostly in hospital environments and possibly with immunocompromised subjects. It is also important to highlight that the increase in outbreaks has been strongly associated with the consumption of vegetables by immunocompromised individuals [47].

Organic agriculture production can be associated with other benefits, especially regarding sustainability and public health. Brazil, for example, is the leading country in the use of pesticides (5.2 L per capita/year), causing a strong impact on the environment in terms of the depletion of natural resources, the persistence of certain residues, and a decrease in biodiversity. The effects on public health due to the consumption of contaminated food, as well as on farm workers due to pesticide intoxication, can be considered as a violation of human rights: violating the right to health and to adequate and healthy food [48].

\section{Conclusion}

The present study showed that the same cultivars of leafy vegetables obtained by organic cultivation had lower microbial counts than those obtained by conventional cultivation.

The methodological approach of the present study does not allow to conclude which cropping system is safer; however, the observed results indicate that leafy vegetables 
cultivated in a conventional way can present a higher count of microorganisms even after the use of chemosynthetic pesticides and fertilizers. In this sense, good farming practices, independent of the cropping system, tend to be more effective in controlling the microbiological load. The quality of the water and the type of irrigation used in production can affect the quality of the leafy vegetables, so they should be carefully evaluated and implemented.

Anyway, the detection of some Enterobacteriaceae species (but no Salmonella specie) in various types of leafy vegetable from both farming systems raises concern about the consumption of raw vegetables by susceptible individuals, such as infants, the elderly, and immunocompromised persons.

\section{Additional Points}

Practical Applications. The organic market is increasing worldwide. Agriculture for local consumption and exportation is the main economic activity in Brazil. As a result of that, the country is leading pesticide use $(5.2 \mathrm{~L}$ per capita/year) and the study of organic production is important to give the opportunity to the population to reduce chemical exposure. The microbiological quality of leafy vegetable from organic farming was compared to conventional farming and showed no greater microbial load to them.

\section{Conflicts of Interest}

The authors declare no conflicts of interest.

\section{Acknowledgments}

The authors are grateful to the National Council for Scientific and Technological Development (CNPq) for the scholarships provided (129891/2019-9 and 303568/2016) and for financial support from the Sao Paulo Research Foundation (FAPESP, Project 2013/04304-4). The authors are grateful also to the students Gisele V. R. Pereira, Larissa T. Silva, and Franciele C. Silva for technical assistance.

\section{References}

[1] H. Willer and J. Lernoud, "The World of Organic Agriculture: Statistics and Emerging Trends," Research Institute of Organic Agriculture (FiBL), Frick, and IFOAM - Organics International, Bonn, Germany, 2017, http://www.organic-world.net/yearbook/ yearbook-2017.htmll.

[2] M. Liu, "Brazilian Organic Market Trends and News BIOFACH," http://www.organicsbrasil.org/upload/downloads/ 2015-Organics-Brasil-Biofach-Conference-painel.pdf, 2015.

[3] D. Bourn and J. Prescott, "A comparison of the nutritional value, sensory qualities, and food safety of organically and conventionally produced foods," Critical Reviews in Food Science and Nutrition, vol. 42, no. 1, pp. 1-34, 2002.

[4] N. Michaelidou and L. M. Hassan, "The role of health consciousness, food safety concern and ethical identity on attitudes and intentions towards organic food," International Journal of Consumer Studies, vol. 32, no. 2, pp. 163-170, 2008.
[5] X. Yu and H. Yang, "Pyrethroid residue determination in organic and conventional vegetables using liquid-solid extraction coupled with magnetic solid phase extraction based on polystyrene-coated magnetic nanoparticles," Food Chemistry, vol. 217, pp. 303-310, 2017.

[6] A. Saba and F. Messina, "Attitudes towards organic foods and risk/benefit perception associated with pesticides," Food Quality and Preference, vol. 14, no. 8, pp. 637-645, 2003.

[7] S. Ceuppens, C. T. Hessel, R. De Quadros Rodrigues, S. Bartz, E. C. Tondo, and M. Uyttendaele, "Microbiological quality and safety assessment of lettuce production in Brazil," International Journal of Food Microbiology, vol. 181, pp. 67-76, 2014.

[8] S. Wießner, B. Thiel, J. Krämer, and U. Köpke, "Hygienic quality of head lettuce: Effects of organic and mineral fertilizers," Food Control, vol. 20, no. 10, pp. 881-886, 2009.

[9] J. M. Garcia and P. Teixeira, "Organic versus conventional food: A comparison regarding food safety," in Food Reviews International, pp. 1-23, Taylor \& Francis, 2016.

[10] Q. Liu, C. S. Cedric Tan, H. Yang, and S. Wang, “Treatment with low-concentration acidic electrolysed water combined with mild heat to sanitise fresh organic broccoli (Brassica oleracea)," LWT- Food Science and Technology, vol. 79, pp. 594-600, 2017.

[11] J. Zhang and H. Yang, "Effects of potential organic compatible sanitisers on organic and conventional fresh-cut lettuce (Lactuca sativa Var. Crispa L)," Food Control, vol. 72, pp. 20-26, 2017.

[12] Brasil, "Instrução normativa," Ministério da Agricultura, Pecuária e Abastecimento, no. 46, Brazil, 2011.

[13] G. S. Johannessen, R. B. Frøseth, L. Solemdal, J. Jarp, Y. Wasteson, and L. M. Rørvik, "Influence of bovine manure as fertilizer on the bacteriological quality of organic Iceberg lettuce," Journal of Applied Microbiology, vol. 96, no. 4, pp. 787-794, 2004.

[14] F. Magkos, F. Arvaniti, and A. Zampelas, "Organic food: Buying more safety or just peace of mind? A critical review of the literature," Critical Reviews in Food Science and Nutrition, vol. 46, no. 1, pp. 23-56, 2006.

[15] "USA, CDC. Multistate Outbreak of Shiga Toxin-Producing Escherichia Coli O157:H7 Infections Linked to Organic Spinach and Spring Mix Blend (Final Update)," https://www.cdc.gov/ ecoli/2012/O157H7-11-12/, 2012.

[16] J. A. Painter, R. M. Hoekstra, T. Ayers et al., "Attribution of foodborne illnesses, hospitalizations, and deaths to food commodities by using outbreak data, United States, 1998-2008," Emerging Infectious Diseases, vol. 19, no. 3, pp. 407-415, 2013.

[17] E. Scallan, R. M. Hoekstra, F. J. Angulo et al., "Foodborne illness acquired in the United States-major pathogens," Emerging Infectious Diseases, vol. 17, no. 1, pp. 7-15, 2011.

[18] E. C. D. Todd, J. D. Greig, C. A. Bartleson, and B. S. Michaels, "Outbreaks where food workers have been implicated in the spread of foodborne disease. Part 3. Factors contributing to outbreaks and description of outbreak categories," Journal of Food Protection, vol. 70, no. 9, pp. 2199-2217, 2007.

[19] E. C. Redmond and C. J. Griffith, "A comparison and evaluation of research methods used in consumer food safety studies," International Journal of Consumer Studies, vol. 27, no. 1, pp. 1733, 2003.

[20] W. McGlynn, "Guidelines for use of chlorine bleach as a sanitizer in food processing operations," vol. FAPC-116, Stillwater, Okla, USA, 2004, http://gotopinion.info/health/pdf/FAPC116web.pdf.

[21] F. R. Downes and K. Ito, Compendium of Methods for the Microbial Examination of Foods, American Public Health Association, Washington, Wash, USA, 4th edition, 2001. 
[22] W. H. Andrews and T. S. Hammack, "Salmonella," Food and Drug Administration, In Bacteriological Analytical Manual, 8th edition, 2007, http://www.fda.gov/downloads/Food/FoodScienceResearch/UCM309839.pdf.

[23] K. H. Solomon, A. M. E. El-Gindy, and S. R. Ibatullin, Planning and System Selection.In Design and Operation of Farm Irrigation Systems, Chapter 3, American Society of Agricultural and Biological Engineers, St. Joseph, Mich, USA, 2nd edition, 2007.

[24] Brasil, "Resolução da diretoria colegiada," Agencia Nacional de Vigilância Sanitária, no. 12, Brazil, 2001.

[25] ICMSF, "Sampling for Microbiological Analysis: Principles and Specific Applications," in Micro-Organisms in Foods 2, Blackwell Scientific Publications, 2nd edition, 1986.

[26] D. F. Maffei, N. F. D. A. Silveira, and M. D. P. L. M. Catanozi, "Microbiological quality of organic and conventional vegetables sold in Brazil," Food Control, vol. 29, no. 1, pp. 226-230, 2013.

[27] H. Gourama, "A preliminary mycological evaluation of organic and conventional foods," Food Protection Trends, vol. 35, no. 5, pp. 385-391, 2015.

[28] K. A. Arbos, R. J. Freitas, S. C. Stertz, and L. A. Carvalho, "Segurança alimentar de hortaliças orgânicas: aspectos sanitários e nutricionais," Ciência e Tecnologia de Alimentos, vol. 30, pp. 215220, 2010.

[29] M. C. Lotto and P. J. Valarini, "Avaliação da Contaminção de Coliformes Fecais Em Alface (Lactuca Sativa), Água de Irrigação E Lavagem Em Sistemas de Produção Orgânica E Convencional," Revista Brasileira de Agroecologia, vol. 2, no. 2, pp. 1625-1628, 2007, https://www.embrapa.br/busca-de-publicacoes/-/publicacao/15560/avaliacao-da-contaminacao-de-coliformes-fecais-em-alface-lactuca-sativa-agua-de-irrigacao-e-lavagemem-sistemas-de-producao-organica-e-convencional.

[30] D. L. Rizzo, "Alface Orgânica-Avaliação Microbiológica Relacionada Ao Sistema de Produção E Processamento Mínimo E Estudo de Sua Aceitação Sensorial," Brazil, Universidade de São Paulo, 2014.

[31] A. S. Sant'Ana, M. Landgraf, M. T. Destro, and B. D. G. M. Franco, "Prevalence and counts of Salmonella spp. in minimally processed vegetables in São Paulo, Brazil," Food Microbiology, vol. 28, no. 6, pp. 1235-1237, 2011.

[32] L. R. Santana, R. D. Carvalho, C. C. Leite, L. M. Alcântara, T. W. Oliveira, and B. d. Rodrigues, "Qualidade física, microbiológica e parasitológica de alfaces (Lactuca sativa) de diferentes sistemas de cultivo," Ciência e Tecnologia de Alimentos, vol. 26, no. 2, pp. 264-269, 2006.

[33] M. Oliveira, J. Usall, I. Viñas, M. Anguera, F. Gatius, and M. Abadias, "Microbiological quality of fresh lettuce from organic and conventional production," Food Microbiology, vol. 27, no. 5, pp. 679-684, 2010.

[34] S. Park, B. Szonyi, R. Gautam, K. Nightingale, J. Anciso, and R. Ivanek, "Risk factors for microbial contamination in fruits and vegetables at the preharvest level: A systematic review," Journal of Food Protection, vol. 75, no. 11, pp. 2055-2081, 2012.

[35] ICMSF, "Microbial Ecology of Food Commodities," in MicroOrganisms in Foods 6, Springer USA, Boston, Mass, USA, 2nd edition, 2005.

[36] J. d. Malty, J. O. Siqueira, and F. M. Moreira, "Efeitos do glifosato sobre microrganismos simbiotróficos de soja, em meio de cultura e casa de vegetação," Pesquisa Agropecuária Brasileira, vol. 41, no. 2, pp. 285-291, 2006.

[37] S. Sahni, B. K. Sarma, D. P. Singh, H. B. Singh, and K. P. Singh, "Vermicompost enhances performance of plant growthpromoting rhizobacteria in Cicer arietinum rhizosphere against
Sclerotium rolfsii," Crop Protection, vol. 27, no. 3-5, pp. 369-376, 2008.

[38] M. A. Orrico Júnior, A. C. Orrico, and J. d. Lucas Júnior, “Compostagem da fração sólida da água residuária de suinocultura," Engenharia Agrícola, vol. 29, no. 3, pp. 483-491, 2009.

[39] M. P. Bernal, J. A. Alburquerque, and R. Moral, "Composting of animal manures and chemical criteria for compost maturity assessment: a review," Bioresource Technology, vol. 100, no. 22, pp. 5444-5453, 2009.

[40] M. S. Costa, L. A. Costa, A. Pelá, C. J. Silva, L. D. Decarli, and U. F. Matter, "Desempenho de quatro sistemas para compostagem de carcaça de aves," Revista Brasileira de Engenharia Agrícola e Ambiental, vol. 10, no. 3, pp. 692-698, 2006.

[41] S. S. Gnanamanickam, Plant-Associated Bacteria, Springer, Dordrecht, Netherlands, 2007.

[42] Z. S. Al-Kharousi, N. Guizani, A. M. Al-Sadi, I. M. Al-Bulushi, and B. Shaharoona, "Hiding in Fresh Fruits and Vegetables: Opportunistic Pathogens May Cross Geographical Barriers," International Journal of Microbiology, vol. 2016, Article ID 4292417, 2016.

[43] S. Octavia and R. Lan, "The family enterobacteriaceae," in The Prokaryotes, pp. 225-286, Springer Berlin, Heidelberg, Germany, 2014.

[44] J. M. Jay, M. J. Loessner, and D. A. Golden, "Modern Food Microbiology," in Food Science Text Series, J. M. Jay, Ed., Springer USA, Boston, Mass, USA, 7th edition, 2005.

[45] J. G. A. Al-grawi, "Hafnia alvei urinary tract infection," Iraqi Postgraduate Medical Journal, vol. 7, no. 1, 2008, http://iasj.net/ iasj?func=fulltext\&amp;aId=35589.

[46] A. R. Junqueira, L. S. Sampaio, L. R. Fleming, and J. S. Nascimento, "Diversidade E perfil de resistência a antibióticos de coliformes isolados de saladas comercializadas em restaurantes self-service," Estudos de Biologia, vol. 30, pp. 56-62, 2008, http://www2.pucpr.br/reol/index.php/BS?ddl=4611\&amp;dd99= view.

[47] L. R. Beuchat, "Ecological factors influencing survival and growth of human pathogens on raw fruits and vegetables," Microbes and Infection, vol. 4, no. 4, pp. 413-423, 2002.

[48] F. F. Carneiro, "Dossiê ABRASCO: Um Alerta Sobre Os Impactos Dos Agrotóxicos Na Saúde," Associação Brasileira de Saúde Coletiva - ABRASCO, 2015. 


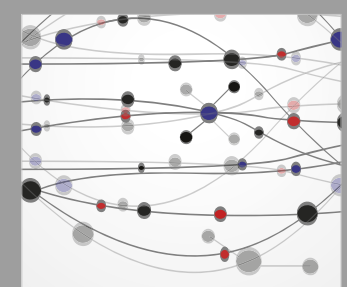

The Scientific World Journal
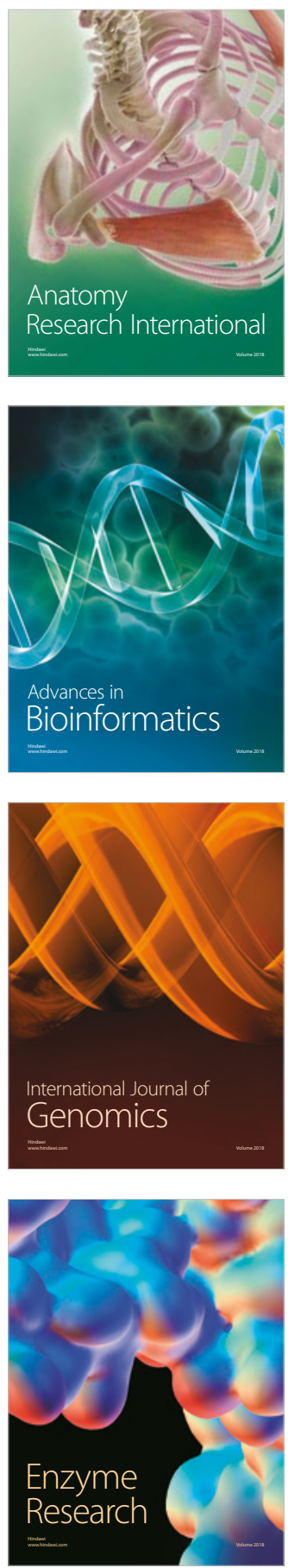
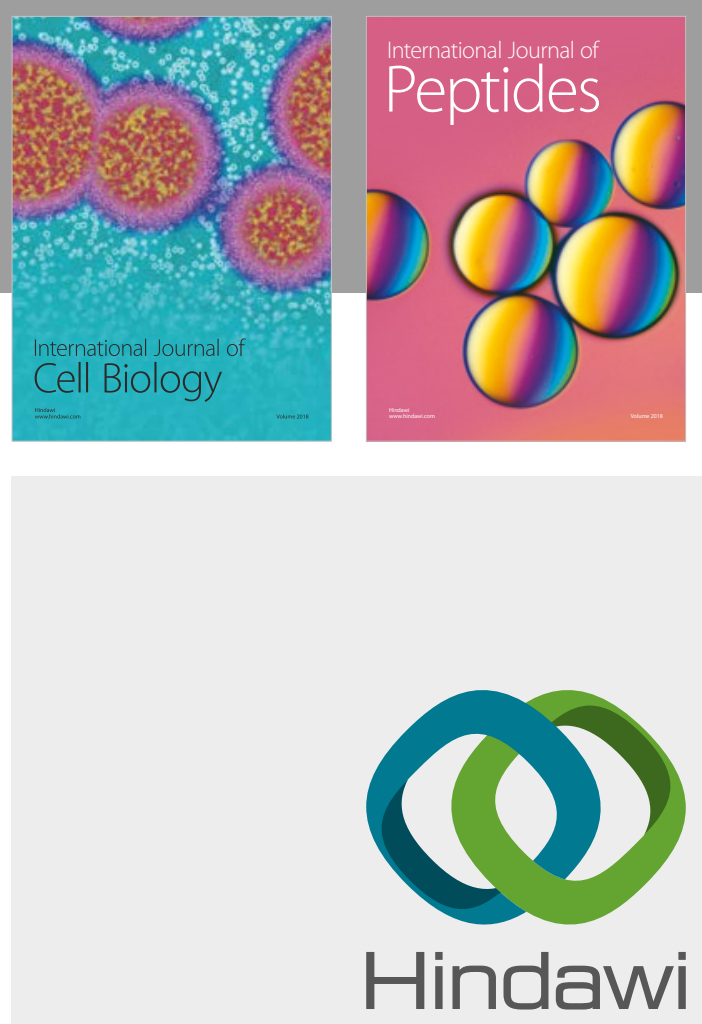

Submit your manuscripts at

www.hindawi.com
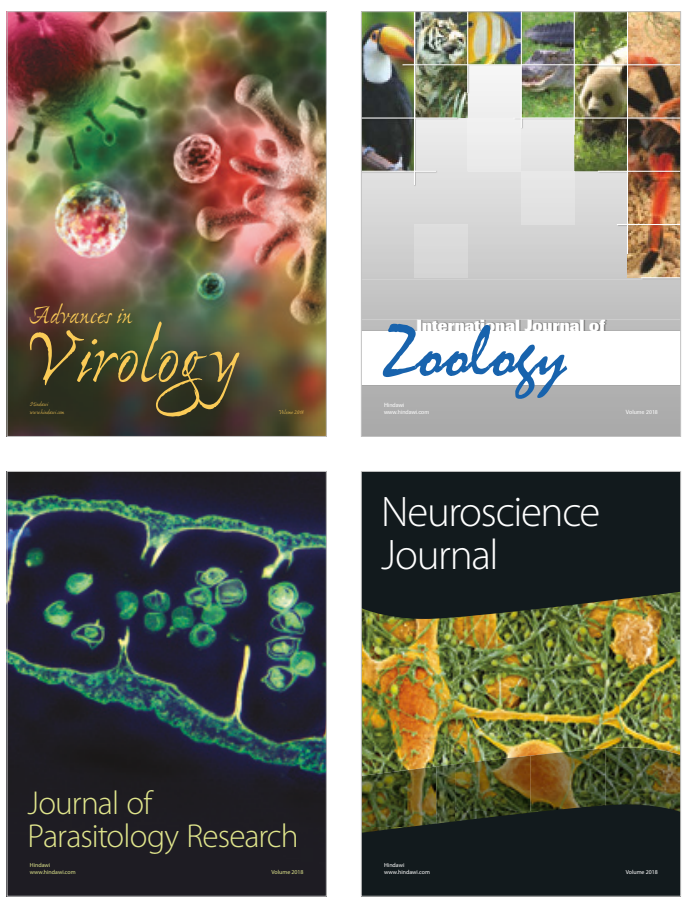
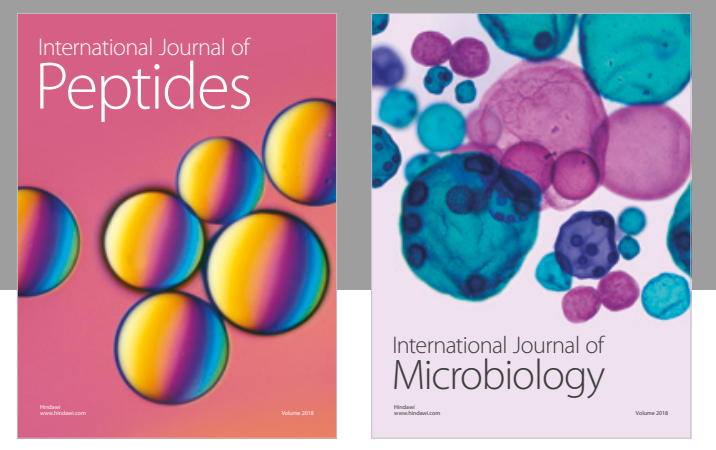

nternational Journal of Microbiology
Journal of
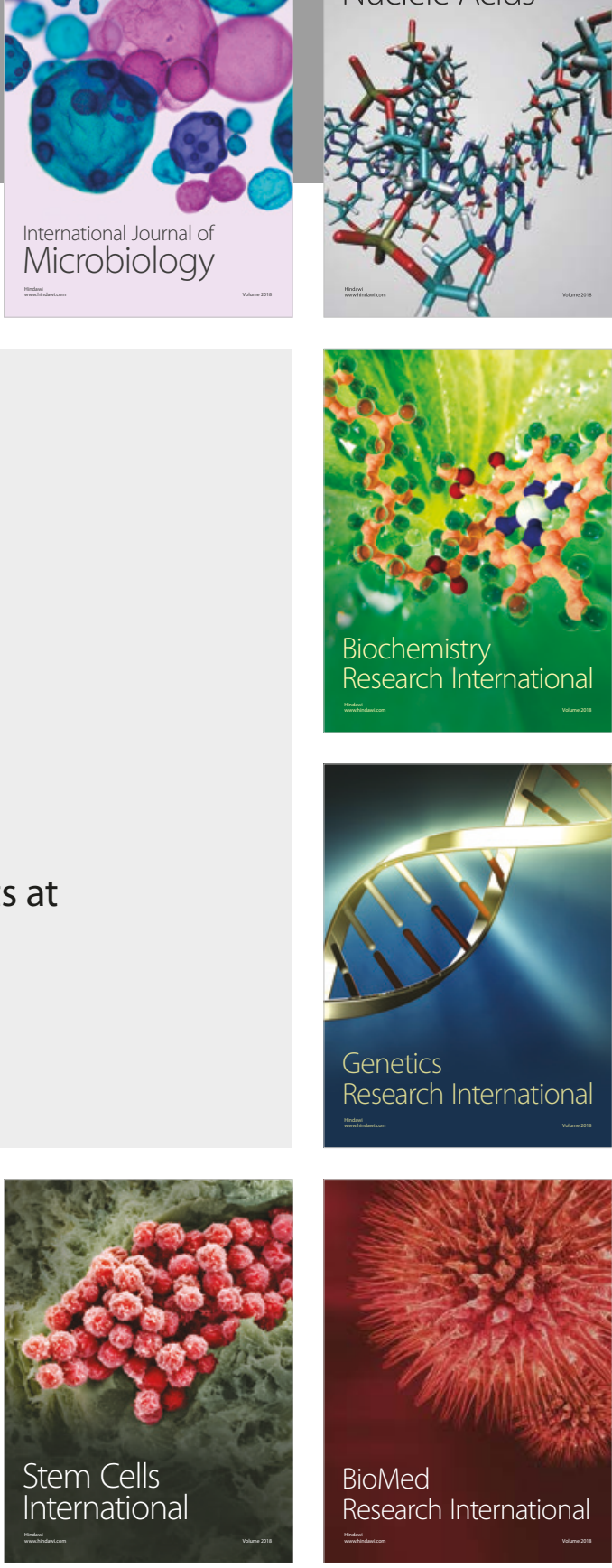
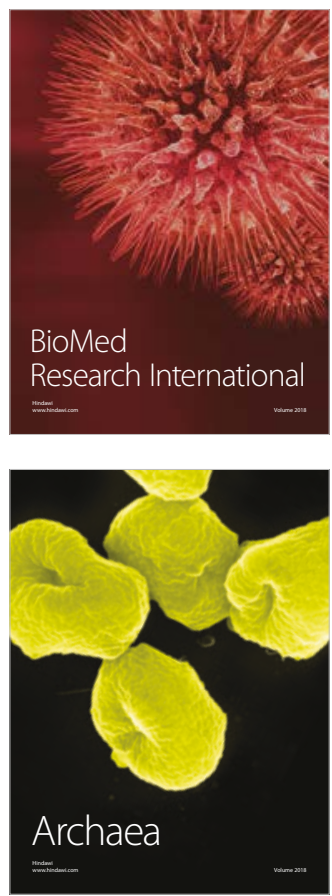